\title{
EVALUASI PENGELOLAAN UNIT PRODUKSI DI SMK NEGERI 1 MANDAU
}

\author{
Lydia Oktaviany ${ }^{1)}$ \\ Azhar ${ }^{2)}$ \\ Sudirman AS ${ }^{3)}$ \\ ${ }^{1)}$ Post Graduate Student of Riau University \\ ${ }^{2)}$ Lecturer of Education Management Study Programme PPs University of Riau \\ ${ }^{3)}$ Lecturer of Education Management Study Programme PPs University of Riau
}

\begin{abstract}
The purpose of this research is to know and analyze the implementation of program management unit production in SMK Negeri 1 Mandau in terms of context, input, process and product activity. This study used a qualitative approach with the type of case study research. Based on the aspects evaluated in this research, the evaluation model of Context (C), Input (I), Process (P), and Product (P) or CIPP is used. The subjects in this study are the principal, head of production units and students who follow the activities of the production unit. Data collecting techniques in this study are interviews, observation, documentation and questionnaires. Data analysis is done through data collection, data reduction, data presentation and verification and conclusion. The results of processing and data analysis show that (1) The implementation of the context component has not been done well, because the environmental conditions are less supportive. (2) Implementation of the input component has been running well enough, planning and organizing of resources has been done in accordance with organizational management prerequisites. (3) The implementation of process components has been running well enough, the implementation and supervision of activities are in accordance with the planning. (4) The implementation of product components has been running well, production unit activities have been able to create students who have entrepreneurial spirit, have skill and competitive and master technology in line with national education objectives.
\end{abstract}

\section{Key words: Evaluation, Management, Production Unit, SMK Negeri 1 Mandau}

ABSTRAK: Tujuan penelitian ini adalah untuk mengetahui dan menganalisis keterlaksanaan pengelolaan program unit produksi di SMK Negeri 1 Mandau ditinjau dari konteks, input, proses dan produk kegiatan. Penelitian ini menggunakan pendekatan kualitatif dengan jenis penelitian studi kasus. Berdasarkan aspek-aspek yang dievaluasi dalam penelitian ini, digunakan model evaluasi Context (C), Input (I), Process (P), dan Product (P) atau yang biasa disinglkat CIPP. Adapun subjek dalam penelitian ini adalah kepala sekolah, ketua unit produksi dan siswa yang mengikuti kegiatan unit produksi. Teknik pengumpul data dalam penelitian ini yakni wawancara, observasi, dokumentasi serta kuisioner. Analisa data dilakukan melalui pengumpulan data, reduksi data, penyajian data dan verifikasi serta penarikan kesimpulan. Hasil pengolahan dan analisis data menunjukkan bahwa (1) Keterlaksanaan komponen konteks masih belum terlaksana dengan baik, karena kondisi lingkungan yang kurang mendukung. (2) Keterlaksanaan komponen input sudah berjalan dengan cukup baik, perencanaan dan pengorganisasian sumber daya sudah dilakukan sesuai dengan prasyarat manajemen organisasi. (3) Keterlaksanaan komponen proses sudah berjalan dengan cukup baik, pelaksanaan serta pengawasan kegiatan sudah sesuai dengan perencanaan. (4) Keterlaksanaan komponen produk sudah berjalan dengan baik, kegiatan unit 
produksi sudah mampu menciptakan siswa yang memiliki jiwa wirausaha, memiliki skill dan kompetitif serta menguasai teknologi sejalan dengan tujuan pendidikan nasional.

Kata Kunci: Evaluasi, Pengelolaan, Unit Produksi.

\section{PENDAHULUAN}

Sekolah Menengah Kejuruan (SMK) adalah lembaga pendidikan yang berorientasi untuk mampu mencetak tenaga kerja yang terampildan professional agar siap terjun langsung di dunia usaha maupun dunia industri, serta selalu berusaha menyesuaikan keterampilan yang dimiliki lulusannya dengan mengembangkan sikap professional. Salah satu upaya yang dilakukan dengan membiasakan siswa melaksanakan praktek produktif dengan nuansa industri yang sebenarnya yaitu melalui kegiatan unit produksi di sekolah. Keterlibatan siswa pada unit produksi selain untuk memperkuat keterampilan (hard skill) yang dimiliki peserta didik juga untuk belajar mengelola jenis usaha (soft skill).

Seiring dengan perkembangan zaman yang semakin maju, dalam dunia industri juga mengalami perkembangan yang sangat pesat sehingga membutuhkan tenaga terampil yang siap kerja didunia industri. Untuk menghadapi kenyataan diatas maka diperlukan unsur atau komponen yang mendukung dalam pengelolaan unit produksi yang mencakup sumber daya manusia, dana, sarana prasarana, serta aktivitas atau kegiatan unit produksi. Sumber daya yang ada tersebut difokuskan dalam fungsi manajemen yang sangat fundamental. Fungsi manajemen digunakan untuk mengelola semua komponen diatas agar unit produksi dapat terselenggara dengan efektif dan efisien.

Namun demikian aktual di lapangan, upaya pengelolaan unit produksi belum berjalan sebagaimana mestinya. Berdasarkan observasi awal di SMK N 1 Mandau, terdapat gejala umum yang sekaligus menjadi kendala utama pelaksanaan kegiatan unit produksi, yaitu (1) terbatasnya modal usaha untuk biaya pembelian alat dan bahan, dari dana yang dibutuhkan untuk persiapan unit produksi sebesar
Rp.390.000.000,- sekolah hanya mampu memperoleh dana bantuan dari pemerintah serta pengelola sebesar kurang lebih Rp.65.000.000,(2) guru mengalami kesulitan dalam membagi waktu antara waktu mengajar di kelas dan sebagai guru pembimbing unit produksi. Kesibukan yang dimiliki oleh guru yang dituntut untuk mengajar minimal 24 jam perminggu disertai dengan tuntutan pekerjaan seperti persiapan membuat bahan ajar, koreksi dan penilai membuat tugas guru sudah cukup pada kegiatan praktek kejuruan; (3) kurangnya komunikasi antar sesama guru di sekolah, belum semua guru memiliki persepsi yang sama dalam memahami program pengengolaan unit produksi, sehingga masih ada guru yang keberatan jika ada siswa di kelasnya yang mengikuti kegiatan unit produksi pada saat jam pelajaran; (4) guru yang diberi tugas membimbing siswa sebagian besar tidak terlibat langsung dalam kegiatan di unit produksi, sehingga guru pembimbing kurang leluasa dalam mengarahkan siswa; (5) pengawasan hanya dilakukan pada proses produksi dan tidak hanya Standar Operasional Prosedur ataupun standar tertentu dalam melakukan pengawasan.

Berdasarkan uraian latar berlakang di atas, maka peneliti bermaksud mengungkap "Evaluasi Pengelolaan Unit Produksi Di SMK Negeri 1 Mandau”.

Evaluasi berasal dari kata bahasa inggris "evaluation" yang diserap dalam perbendaharaan istilah bahasa Indonesia dengan tujuan mempertahankan kata aslinya dengan sedikit penyesuaian laval Indonesia menjadi “evaluasi” yang dapat diartikan memberikan penilaian dengan membandingkan sesuatu hal dengan satuan tertentu sehingga bersifat kuantitatif. Pengertian evaluasi yang bersumber dari kamus Oxford Advance Learner's 
Dictionary of Current English evaluasi adalah to find out, decide the amount or value yang artinya suatu upaya untuk menentukan nilai atau jumlah. Selain arti berdasarkan terjemahan, katakata yang terkandung dalam defenisi tersebut menunjukkan bahwa kegiatan evaluasi harus dilakukan secara berhati-hati, bertanggung jawab, menggunakan strategi dan dapat dipertanggung jawabkan( Suharsimi, 2001:1).

Evaluasi adalah kegiatan untuk mengumpulkan informasi tentang berkerjanya sesuatu, yang selanjutnya informasi tersebut digunakan untuk menentukan alternatif yang tepat dalam mengambil sebuah keputusan (Arikunto dan Cepi, 2008). Selanjutnya kedua ahli ini mengemukakan bahwa mengadakan evaluasi adalah melakukan pengukuran dan penilaian. Mengukur adalah membandingkan sesuatu dengan suatu ukuran. Pengukuran bersifat kuantitatif. Sedangkan menilai adalah mengambil suatu keputusan terhadap sesuatu dengan ukuran baik atau buruk. Penilaian bersifat kualitatif. Dalam istilah asingnya, pengukuran adalah measurement, sedang penilaian adalah evaluation. Dari kata evaluation inilah diperoleh kata indonesia evaluasi yang berarti menilai (tetapi dilakukan dengan mengukur terlebih dahulu). Alat evaluasi juga dikenal dengan instrumen evaluasi. Dalam kegiatan evaluasi, fungsi alat juga untuk diperoleh hasil yang lebih baik sesuai dengan kenyataan yang dievaluasi dan ada dua teknik evaluasi, yaitu teknik nontes dan teknik tes. Ralp Tyler (1950) yang dikutip oleh Suharsimi dan Cepi Safrudin Abdul Jabar (2009: 5) mendefinisikan bahwa evaluasi program adalah proses untuk mengetahui apakah tujuan program sudah dapat terealisasi. Sedangkan Cronbach (1963) dan Stufflebeam (1971) yang dikutip oleh Suharsimi dan Cepi Safrudin Abdul Jabar (2009: 5), evaluasi program adalah upaya untuk menyediakan informasi untuk disampaikan kepada pengambil keputusan.

Dari berbagai definisi tersebut di atas, dapat disimpulkan bahwa yang dimaksud dengan evaluasi adalah kegiatan untuk mengumpulkan informasi tentang bekerjanya sesuatu program, yang selanjutnya informasi tersebut digunakan untuk menentukan alternative atau pilihan yang tepat dalam mengambil sebuah keputusan.

\section{Model Evaluasi Context, Input, Proccess,Dan Product (CIPP)}

Model evaluasi CIPP mulai dikembangkan oleh Daniel L. Stufflebeam (1996) yang dikutip oleh Wirawan (2011: 92), mendefinisikan evaluasi sebagai proses melukiskan (delineating) memperoleh dan menyediakan informasi yang berguna untuk mengambil altrnatif-alternatif pengambil keputusan. Melukiskan artinya menspesifikasikan dan menjelaskan untuk memfokuskan dan mengambil informasi yang dibutuhkan oleh para pengambil keputusan. Memperoleh artinya memakai pengukuran dan statistic mengumpulkan, mengorganisasi, dan menganalisis informasi. Menyediakan artinya mensintesiskan informasi sehingga akan melayani dengan baik kebutuhan informasi para pemangku kepentingan evaluasi.

Menurut Arikunto (2008:40) model evaluasi CIPP merupakan model evaluasi yang terdiri dari empat komponen evaluasi yaitu :Context, Input, Process, dan Product. Komponen evaluasi program CIPP pada dasarnya merupakan komponen dari prosesi sebuah kegiatan.Mengacu pada komponen CIPP, evaluasi program jenis ini merupakan evaluasi yang dilakukan dengan menganalisis komponen-kompenen itu sendiri.

Daniel L.Stufflebeam (2003) yang dikutip oleh Wirawan (2011:92) menyatakan model evaluasi CIPP merupakan kerangka yang komprehensif untuk mengarahkan pelaksanaan evaluasi formatif dan evaluasi sumatif terhadap objek program, proyek, personalia, produk, institusi dan sistem. Model evaluasi ini dikonfigurasiuntuk dipakai oleh evaluator internal yang dilakukan oleh organisasi evaluator, evaluasi diri yang dilakukan oleh tim proyek atau penyedia layanan individual yang dikontrak atau evaluator eksternal. Model evaluasi ini dipakai secara meluas diseluruh dunia dan dipakai untuk mengevaluasi berbagai disiplin dan layanan, 
misalnya pendidikan, perumahan, pengembangan masyarakat, transportasi dan sistem evaluasi personalia militer.

Secara sederhana model evaluasi CIPP dapat dijelaskan sebagai berikut :

1. Evaluasi konteks (context) menentukan kebutuhan, masalah-masalah asset, dan kesempatan untuk membantu mengambil keputusan menetapkan tujuan dan prioritas serta membantu kelompok lebih luas dalam memutuskan tujuan, prioritas dan hasil.

2. Evaluasi input (input) menentukan alternative pendekatan, pelaksanaan rencana kegiatan, penyediaan sarana, penyediaan biaya efektif untuk pencapaian kebutuhan dan pencapaian tujuan.

3. Evaluasi proses (process) menilai pelaksanaan rencana untuk membantu staff melaksanakan kegiatan, kemudian membantu pengguna dalam menilai kinerja program, dan menafsirkan hasil.

4. Evaluasi produk (product) mengidentifikasi dan menilai hasil baik jangka pendek maupun jangka panjang untuk membantu staff agar lebih focus pada hasil penting dan hasil akhir serta mengukut keberhasilan upaya dalam memenuhi target yang telah ditetapkan.

\section{Unit Produksi}

Unit produksi merupakan suatu program yang pada awalnya merupakan satu kesatuan dalam program Pengembangan Sekolah Seutuhnya dalam program Pengembangan Sekolah (School Integrated Development) atau lebih dikenal program PSS (PPPGT Bandung, 2007 ).Secara umum unit produksi merupakan suatu proses kegiatan usaha yang dilakukan di dalam sekolah dan bersifat bisnis (profit oriented) serta dilakukan oleh warga sekolah dengan memberdayakan sumber daya sekolah yang dimiliki serta dikelola secara profesional.

Beberapa pengertian unit produksi dari para ahli sebagai berikut: menurut Benny Suprapto (2001) unit produksi adalah "suatu kegiatan yang berfungsi untuk memproduksi barang dan jasa dengan memanfaatkan semua sumber daya yang ada disekolah.” Menurut Y.H.S Sriyanto (2002) unit produksi adalah "Wadah bagi satu atau lebih kegiatan usaha yang potensial dan hasilnya dapat dipasarkan meliputi barang dan jasa.”Sedangkan menurut Ir Tawan Rosidi "Unit produksi di SMK merupakan kegiatan usaha yang bertujuan untuk memperoleh nilai tambah/ keuntungan dari kegiatan usaha.Baik kegiatan usaha jasa atau kegiatan produksi, sehingga diharapkan ada tambahan pemasukan untuk sekolah, yang dapat mendukung Anggaran Pendapatan dan Belanja Sekolah (APBS).”

Menurut Dikmenjur dalam Direktorat Tenaga Kependidikan (2007:8) diuraikan berbagai tujuan penyelenggaraan kegiatan unit produksi, antara lain :

1. Wahana pelatihan berbasis produksi/jasa bagi siswa;

2. Wahana menumbuhkan dan mengembangkan jiwa wirausaha guru dan siswa pada SMK;

3. Sarana praktik produktif secara langsung bagi siswa;

4. Membantu pendanaan untuk pemeliharaan, penambahan fasilitas dan biaya operasional pendidikan lainnya;

5. Menambah semangat kebersamaan, karena dapat menjadi wahana peningkatan aktivitas produktif guru dan siswa serta member "income" serta peningkatan kesejahteraan;

6. Mengembangkan sikap mandiri dan percaya diri dalam pelaksanaan kegiatan praktik siswa;

7. Melatih untuk berani mngambil resiko dengan perhitungan yang matang;

8. Mendukung pelaksanaan dan pencapaian Pendidikan Sistem Ganda (PSG) dan Kurikulum Tingkat Satuan Pendidikan yang seutuhnya;

9. Memberikan kesmpatan pada siswa dan guru untuk mengerjakan praktik yang berorientasi pasar;

10. Meningkatkan kreativitas dan inovasi dikalangan siswa, guru dan manajemen sekolah; 
11. Menumbuhkan sikap profesional produktif pada siswa dan guru;

12. Melatih siswa untuk tidak bergantung pada orang lain;

13. Mandiri khususnya dalam mendapatkan kesempatan kerja;

14. Wadah Pendidikan Sistem Ganda (PSG) bagi siswa yang tidak mendapatkan pekerjaan didunia usaha dan industry;

15. Menjalin hubungan yang lebih baik dengan dunia usaha dan industry serta masyarakat lain atas terbukanya fasilitas untuk umum dan hasil-hasil produksinya;

16. Meningkatkan intensitas dan frekuensi kegiatan intra, ko, dan ekstra kurikuler siswa dan;

17. Membangun kemampuan sekolah dalam menjalin kerjasama sinergis dengan pihak luar dan lingkungan serta masyarakat luar.

Dalam Pedoman Pelaksanaan Unit Produksi (2007) juga dijelaskan tujuan khusus unit produksi antara lain :

1. Menciptakan kemampuan untuk berwirausaha

2. Meningkatkan pelaksanaan praktek

3. Meningkatkan kemampuan koperasi sekolah yang memberikan dampak pada kesejahteraan anggotanya

4. Melatih displin dan kepercayaan diri

5. Melatih keberanian mengambil resiko yang diperhitungkan

6. Siswa akan terampil dibidangnya

7. Meningkatkan sikap mandiri dan percaya diri.

\section{Manajemen Unit Produksi Sekolah}

Manajemen merupakan suatu proses kegiatan yang dilakukan secara terencana, berkesinambungan dan saling berkaitan melalui cara-cara tertentu dengan keterampilan yang dimiliki oleh seseorang untuk mencapai suatu tujuan tertentu dengan memanfaatkan sumber daya secara efektif dan efisien.

Dalam mencapai sebuah tujuan yang akan ditetapkan, diperlukan orang-orang yang dapat diatur dengan menempatkan orang-orang yang tepat pada bidangnya, sehingga melalui orangorang tersebut pekerjaan terlaksana dengan efektif dan efisien serta dapat menghasilkan manfaat bagi semua pihak yang terkait maupun pihaklain.

Unit produksi sebagai suatu kegiatan untuk memproduksi barang atau jasa harus dilaksanakan dan dikelola dengan baik. Untuk menghasilkan suatu produk dan mencapai tujuan kegiatan perlu dilakukan suatu proses atau pengelolaan secara sistematis melalui serangkaian kegiatan manajemen atau dikenal dengan istilah fungsi manajemen. Adapun fungsi manajemen menurut Terry (2008: 77-78) terdiri dari perencanaan, pengorganisasian, pelaksanaan, dan pengawasan. Fungsi-fungsi manajemen tersebut kemudian diterapkan dalam komponenkomponen yang terlibat dalam unit produksi, yaitu meliputi SDM, sarana, biaya dan proses kegiatan unit produksi. Manajemen unit produksi dilaksanakan oleh kepala sekolah dan staf yang ditunjuk sebagai pengelola unit produksi disekolah yang bersangkutan.

\section{METODOLOGI PENELITIAN Pendekatan Penelitian}

Penelitian ini dilakukan berdasarkan pendekatan kualitatif dengan jenis studi kasus sehingga nantinya dapat memberikan gambaran tentang fenomena yang diteliti.

Berdasarkan tujuan evaluasi dan aspekaspek yang dievaluasi dalam kaitannya dengan studi evaluatif pengelolaan unit produksi dalam kaitannya dengan pendidikan berbasis produksi di SMK Negeri 1 Mandau, dipilih model evaluasi CIPP yaitu Context Evaluation, Input Evaluation, Process Evaluation, dan Product Evaluation, karena program yang dievaluasi berdasarkan 4 (empat) komponen konteks, input, proses, produk dan informasi yang diperlukan mengangkut keempat komponen tersebut.

Subjek dalam penelitian ini adalah kepala sekolah, ketua unit produksi dan siswa yang mengikuti kegiatan unit produksi. Unit produksi yang diteliti adalah unit produksi di SMK Negeri 1 Mandau. Dikarenakan ketua unit produksi dan 
kepala bengkel adalah sekaligus merangkap maka beliau adalah sebagai informan karena secara struktural memiliki otoritas dan wewenang yang kuat dalam mengelola unit produksi, mulai dari perencanaan, pengorganisasian, pelaksanaan, pengawasan serta output kegiatan.

Pengumpulan data penelitian ini dilakukan dengan melakukan wawancara, observasi, kuisioner dan dokumentasi kepada subjek penelitian seperti kepala sekolah, ketua unit produksi dan siswa, dengan alasan sebagai sumber informasi untuk memperoleh data primer mengenai pengelolaan unit produksi.

Peneliti merupakan instrument utama dalam penelitian ini karena peneliti bertindak secara aktif sebagai pengumpul data di lapangan. Kehadiran peneliti tidak ditujukan untuk mempengaruhi subjek tetapi untuk mendapatkan data yangh akurat secara langsung pada sumber data. Dalam penelitian ini membut uhkan alat bantu atau instrument yang befungsi mempermudah peneliti mendapatkan dan mengumpulkan data atau informasi dari subjek dan objek yang diteliti.

Instrumen disusun dengan mengacu pada kajian teoritis yang diturunkan dalam definisi operasional penelitian, dilanjutkan dengan menentukan indikator setiap variabel, kemudian menyusun kisi-kisi instrumen yang berisi indikator dan item-item instrumen penelitian.

\section{HASIL DAN PEMBAHASAN}

\section{Keterlaksanaan Komponen Konteks}

Sub Fokus 1 : keterlaksanaan komponen konteks dilihat dari kondisi lingkungan yang mendukung kegiatan unit produksi di SMK Negeri 1 Mandau

Konteks dalam program unit produksi di SMK Negeri 1 Mandau ditinjau dari kondisi lingkungan yang mendukung pelaksanaan program. Hal ini mencakup segala permasalahan yang dihadapi para pembimbing pembelajaran berbasis produksi (PBE), seperti : kurangnya komunikasi antar sesama guru di sekolah, belum semua guru memiliki persepsi yang sama dalam memahami program pengengolaan unit produksi, sehingga masih ada guru yang keberatan jika ada siswa di kelasnya yang mengikuti kegiatan unit produksi pada saat jam pelajaran dan sebagainya.

Berdasarkan temuan kualitatif hasil penelitian menunjukkan bahwa kurangnya komunikasi antar sesama guru dalammendukung pelaksanaan unit produksi di SMK Negeri 1 Mandau. Selain itu, guru-guru banyak yang tidak satu persepsi mengenai tujuan dan manfaat unit produksi sebagai sumber pendanaan pendidikan. Tidak hanya guru, orang tua sebagai stakeholder pun juga belum memiliki kesamaan persepsi mengenai manfaat unit produksi. Sebagian dari mereka beranggapan bahwa jadwal praktek unit produksi mengurangi waktu istirahat siswa sehingga tidak fokus lagi untuk belajar dikelas. Sebagai mana dikemukakan oleh Ketua Unit Produksi bahwa :

"Kendala utama saat ini yang kami hadapi ialah kurangnya komunikasi antar guru untuk mendukung pelaksanaan unit produksi. Sebagian guru berpendapat bahwa unit produksi akan mengganggu jam belajar siswa sehingga kebanyakan dari mereka sering tidak member izin siswa untuk mengikuti kegiatan ini setelah jam pelajaran. Alhasil kami tidak bisa memaksakan, sehingga hanya siswa yang diberikan izin oleh guru mata pelajaranlah yang dapat mengikuti kegiatan. Begitupun adanya dengan dukungan dari orang tua siswa, jadwal kegiatan unit produksi yang terkadang bisa hingga malam hari (jika banyak pesanan) membuat mereka khawatir akan waktu istirahat anak berkurang sehingga tidak fokus lagi mengikuti pelajaran di kelas”. (Hasil wawancara dengan Ketua Unit Produksi SMK Negeri 1 Mandau, 19 September 2016).

Selanjutnya seperti dikemukakan oleh Ketua unit produksi bahwa jam mengajar guru yang sudah padat juga membuat guru terkendala dalam melakukan kegiatan maupun pengawasan pada kegiatan unit produksi, sehingga banyak siswa yang bekerja tanpa didampingi guru pengawas.

Dari hasil wawancara ini dapat disimpulkan bahwa unit produksi SMK Negeri 1 Mandau dapat disimpulkan bahwa pengelolaan unit produksi terkait komponen keterlaksanaan 
konteks masih belum terlaksana sebagaimana mestinya dikarenakan kondisi lingkungan yang kurang mendukung. Kurangnya dukungan guru mata pelajaran maupun orangtua siswa menjadi kendala utama.

\section{Keterlaksanaan Komponen Input}

Sub Fokus 2 : keterlaksanaan komponen input dilihat ditinjau dari ketersediaan sarana prasarana, sumber daya manusia, perencanaan keuangan dan perencanaan struktur organisasi sehingga dapat mendukung tercapainya tujuan yang ditetapkan.

Berdasarkan temuan kualitatif melalui observasi dan wawancara dengan ketua unit produksi diperoleh data sebagai berikut :

\section{a. Ketersediaan Sarana dan Prasarana}

Perencanaan sarana dan prasarana unit produksi dalam sebuah organisasi haruslah memiliki prosedur yang jelas. Hal ini dimaksudkan agar kemungkinan terjadinya kesalahan-kesalahan akibat pendataan yang tidak jelas dapat dihindarkan. Pendataan dalam unit produksi merupakan hal yang perlu dilakukan dalam perencanaan sarana dan prasarana. Pendataan sarana dan prasarana unit produksi SMK Negeri 1 Mandau sudah ada dalam laporan sub unit produksi SMK Negeri 1 Mandau.

Sebagaimana dikemukakan oleh Ketua unit produksi bahwa :

"Penyiapan sarana dan prasarana untuk menunjang pengelolaan unit produksi di SMK Negeri 1 Mandau disediakan oleh sekolah, dan bila terjadi kekurangan maka dilengkapi menggunakan uang penyusutan alat.” (Hasil wawancara dengan Ketua Unit Produksi SMK Negeri 1 Mandau, 19 September 2016).

Hasil wawancara tersebut menunjukkan bahwa peerencanaan mengenai ketersediaan sarana dan prasarana unit produksi SMK Negeri 1 Mandau sudah terlaksaana sesuai dengan indikator yang ada.

\section{Keterlaksanaan Komponen Proses}

Sub Fokus 3 : keterlaksanaan komponen proses ditinjau dari pelaksanaan SDM, produksi dan keuangan serta pengawasan SDM, produksi dan keuangan unit produksi sehingga dapat mendukung tercapainya tujuan yang ditetapkan.

Keterlaksanaan pengadaan, pengembangan dan pemeliharaan sumber daya manusia diungkap dengan hasil observasi. Dari hasil observasi diperoleh keterangan bahwa pengurus unit produksi terdiri dari ketua unit produksi dan koordinator pelaksana unit produksi. Pelatihan dilakukan oleh masing-masing personel saat mereka bekerja, hal ini terlihat dari kecekatan pekerja, produk yang dihasilkan dan laba produksi yang semakin meningkat.

Pelaksanaan sumber daya manusia di unit produksi melibatkan siswa sebagai pelaksana kegiatan usaha. Hal ini didukung dengan perhitungan hasil kuisioner yang menyebutkan bahwa siswa mendapatkan bimbingan guru pada saat bekerja. Sebagian besar siswa menyatakan mendapatkan uang kompensasi dan sebagian siswa menyatakan bahwa jumlah orang yang bekerja di unit produksi sudah sesuai dengan tingkat kebutuhan usaha.

Hasil perhitungan kuisioner menunjukkan bahwa sebagian besar siswa melakukan kegiatan di unitproduksi dengan bimbingan guru. Sebagian besar siswa menilai bahwa jumlah orang yang bekerja di unit produksi sudah sesuai dengan tingkat kebutuhan usaha. Dalam kegiatan tersebut, siswa mendapatkan uang kompensasi saat praktik di unit produksi.

Dalam aspek pelaksanaan produksi, unit produksi SMK Negeri 1 memproduksi produk pesanan konsumen berupa, teralis, pagar, meja dan bangku sekolah, dan lain-lain. Pembuatan produk disesuaikan dengan kriteria standar yang telah ditemukan unit produksi,yaitu kualitas bahan yang digunakan dan kualitas produk yang dihasilkan.

\section{Keterlaksanaan Komponen Produk}

Sub Fokus 4 : keterlaksanaan komponen produk dalam unit produksi SMK Negeri 1 
Mandau ditinjau dari hasil kesesuaian antara tujuan dengan pelaksanaan program yang telah dicapai dalam pelaksanaan unit produksi di SMK Negeri 1 Mandau .

Berdasarkan temuan kualitatif melalui observasi, kuisioner dan wawancara dengan ketua unit produksi diperoleh data sebagai berikut:

Hasil (Product) dilihat dari hasil yang telah dicapai dalam pelaksanaan unit produksi SMK Negeri 1 Mandau. Dari tujuan program yang ada, hasil observasi menunjukkan bahwa masih terdapat beberapa aspek yang belum memenuhi tujuan program. Seperti dikemukakan oleh ketua unit produksi bahwa "dukungan yang kurang dari guru dan orang tua adalah kendala utama saat ini, para guru pun belum memandang unit produksi sebagai lahan yang menjanjikan sebagai wadah berwirausaha bagi siswa dan guru itu sendiri." Namun disamping itu proses pelaksanaan program dan dampak terhadap siswa semakin meningkat dari tahun ke tahun. Hal ini dapat dilihat dari hasil observasi kesesuaian antara tujuan dan pelaksanaan program yang sudah berjalan di SMK Negeri 1 Mandau.

Hal ini juga didukung dari hasil kuisioner yang menyebutkan hanya sebagian besar siswa menyatakan mendapatkan bimbingan dan arahan dalam melaksanakan kegiatan unit produksi. Siswa juga menyatakan kemampuan dalam berwirausaha menjadi lebih baik, hanya sebagian kecil siswa yang tidak mampu mengembangkan jiwa berwirausahanya. Siswa sudah dapat berfikir secara logis dalam mengambil keputusan dalam kegiatan produksi. Siswa juga telah termotivasi untuk menghadapi dunia kerja sesungguhnya. Hasil ini sejalan dengan teori yang diharapkan bahwa Pengelolaan unit produksi dapat dikatakan efektif apabila sesuai dengan tujuan yang diharapkan, sehingga dapat diketahui hasilnya. Hasil yang dimaksud menurut Rusnani dan Moerdiyanto (2012:7) yaitu efektifitas manajemen kegiatan unit produksi, seperti perencanaan kegiatanan unit produksi menerapkan konsep manajemen yang bermutu sesuai dengan standar yang berlaku, kegiatan produksi terintegrasi dengan proses belajar mengajar, kegiatan produksi unit produksi menjadi alternative pelaksanaan praktik kerja industry sebagai proses pelatihan kewirausahaan, struktur organisasi terintegrasi dengan struktur organisasi sekolah, pemasaran produk melibatkan seluruh warga sekolah, pembukuan dan pertanggung jawaban keuangan dilakukan mengikuti standar akutansi keuangan, pelaporan keuangan dilakukan secara berkala minimal satu tahun sekali, dan lain sebagainya.

\section{SIMPULAN DAN SARAN}

Berdasarkan data dan hasil analisis yang telah dipaparkan diatas, maka dapat diambil beberapa kesimpulan sebagai berikut:

\section{Keterlaksanaan Komponen Konteks}

Pengelolaan unit produksi unit produksi SMK Negeri 1 Mandau pada komponen keterlaksanaan konteks masih belum terlaksana sebagaimana mestinya dikarenakan kondisi lingkungan yang kurang mendukung. Kurangnya dukungan dari guru mata pelajaran serta orang tua terhadap siswa menjadi kendala utama dalam konteks pelaksanaan kegiatan.

\section{Keterlaksanaan Komponen Input}

Perencanaan pengelolaan unit produksi SMK Negeri 1 Mandau sudah dilaksanakan dengan cukup baik. Perencanaan sumber daya manusia yang dilakukan oleh unit produksi SMK Negeri 1 Mandau masih kurang efektif. Pelaksanaan produksi tetap berjalan dengan baik meskipun produk yang dihasilkan berubah-ubah. Perencanaan keuangan yang dilakukan unit produksi SMK Negeri 1 Mandau sudah cukup baik yakni, dalam dituangkan dalam anggaran jangka pendek dan jangka panjang.

Pengorganisasian di unit produksi SMK Negeri 1 Mandau sesuai dengan prasyarat manajemen organisasi. Pengurus unit produksi sebanyak 10 (sepuluh) orang memiliki jabatan fungsional. Pengurus secara defentif adalah guru kejuruan yang diberikan wewenang melalui proses pemilihan untuk mengelola unit produksi. 
Siswa kelas X dan XI bertugas piket pada workshop unit produksi, dan siswa kelas XII bertugas membuat pesanan konsumen.

\section{Keterlaksanaan Komponen Proses}

Pengelolaan unit produksi SMK Negeri 1 Mandau sudah dilaksanakan dengan cukup baik. Pelaksanaan kegiatan-kegiatan sumber daya manusia di unit produksi SMK Negeri 1 Mandau sudah sesuai dengan rencana, namun ada beberapa aspek yang belum terlaksana seperti pelatihan untukguru maupun siswa. Pelaksanaan produksi sudah sesuai dengan perencanaan yaitu produk pesanan. Pelaksanaan produksi juga memperhatikan kualitas bahan dan kualitas produk. Pemasaran di lingkungan sekolah sudah terlaksana dengan baik, namun pemasaran untuk masyarakat umum masih terbatas. Pengelolaan keuntungan dan kerugian juga dilaksanakan sesuai dengan perencanaan, yaitu dengan membagi keuntungan sesuai dengan aturan yang berlaku dan menanggung kerugian menggunakan pengembangan modal.

Pengawasan sumber daya manusia, produksi dan keuangan yang dilakukan oleh unit produksi SMK Negeri 1 Mandau sesuai dengan tindakan pengawasan. Pengawasan pengurus dilakukan oleh kepala sekolah dengan cara berkeliling pada jam tertentu. Jika terjadi kesalahan ketika pengawasan maka kepala sekolah memberikan teguran. Menurut sebagian besar siswa, pada saat piket workshop unit produksi tidak diawasi guru dan setelah usai piket juga tidak dievaluasi guru. Pengawasan produksi dilakukan oleh pengurus, kaprodi, dan kepala sekolah setiap hari ataupun sesuai kebutuhan. Pengawasan terhadap produksi dilakukan dengan membandingkan produk yang dihasilkan dengan produk yang lebih baik ataupun produk yang sesuai standar. Pengawasan pemasaran pada unit produksi dilakukan setiap hari. Pengawasan keuangan dilakukan oleh bendahara, ketua unit dan kepala sekolah sesuai dengan kebutuhan. Pengawasan keuangan ini dapat dilakukan jika suatu proses telah diselesaikan.

\section{Keterlaksanaan Komponen Produk}

SMK Negeri 1 Mandau melalui unit produksi, sudah mampu menciptakan siswa yang memiliki jiwa wirausaha, memiliki skill dan kompetitif serta menguasai teknologi sejalan dengan tujuan pendidikan nasional. Hal ini dapat dibuktikan dengan hasil penelitian yang mana sebagian besar siswa yang terlibat dalam kegiatan unit produksi di SMK Negeri 1 Mandau menyatakan bahwa mereka mampu mengerjakan pekerjaan praktik berorientasi pasar. Mereka juga menyatakan bahwa kompetensi dan pengetahuan mereka juga meningkat setelah mengikuti kegiatan unit produksi.

Dari tahun ke tahun, program yang telah dilaksanakan SMK Negeri 1 Mandau, menunjukkan bahwa program kegiatan telah banyak mengalami peningkatan, bahkan omset penjualan produk saat ini sudah bisa untuk menutupi anggaran kebutuhan belanja sekolah.

\section{Saran}

Berdasarkan temuan penelitian, maka saran yang akan diberikan adalah sebagai berikut:

a. Bagi kepala sekolah, hendaknya meningkatkan perencanaan dengan cara mengajak semua pihak serta guru ikut memikirkan untuk merencanakan kegiatan unit produksi agar sesuai dengan tujuan yang diinginkan agar perencanaan menjadi sangat baik. Peneliti menyarankan dalam perencanaan unit produksi hendaknya melibatkan pihak-pihak yang mengetahui secara jelas pelaksanaan unit produksi atau pihak-pihak sekolah lain yang telah menghasilkan kegiatan unit produksi yang berhasil. Kepala sekolah hendaknya dapat mengadakan pelatihan untuk guru dan pelaksana dari luar atau ahli yang sesuai atau mengarahkan guru untuk mengikuti seminarseminar kewirausahaan dalam sesuai bidang bagi guru, pelaksana dan siswa yang bersangkutan.

b. Bagi guru atau pembina, diharapkan dapat bekerjasama dengan guru mata pelajaran untuk mengkoordinasikan tugas tambahan 
bagi siswa yang piket di unit produksi. Guru atau pembina juga hendaknya dapat mengkoordinasikan antara pengelola unit produksi dan guru mata pelajaran mengenai jadwal ujian harian, agar pelaksanaan sumber daya manusia dapat berjalan efektif dan efisien. Kemudian, guru dan pembina dapat mengupdate pembagian jadwal piket guru di unit produksi dilakukan setiap satu semester atau 6 bulan sekali. Hal ini ditujukan agar kerja guru piket kafetaria efektif karena jadwal mengajar guru dan kerja di unit produksi tidak bertabrakan.

Selanjutnya, rapat bersama orang tua murid juga dapat dilakukan untuk memberikan pengertian bahwa unit produksi adalah salah satu wadah pelatihan untuk siswa sehingga tidak ada lagi orang tua yang khawatir jika anak mengikuti kegiatan ini.

c. Bagi siswa, diharapkan agar memahami betul pentingnya mengikuti kegiatan unit produksi guna membentuk jiwa wirausaha, memiliki skill dan kompetitif serta menguasai teknologi yang sejalan dengan tujuan pendidikan nasional.

\section{DAFTAR PUSTAKA}

Anas Sudiyono, 2006. Pengantar Evaluasi Pendidikan. Jakarta : PT. Raja Grafindo Persada.

Burhan Bungin, 2008.Penelitian Kualitatif ;Komunikasi, Ekonomi, Kebijakan Publik, dan Ilmu Sosial Lainnya Edisi Kedua. Jakarta. Kencana Prenada Media Group.

B Suryosubroto, 2006. Manajemen Pendidikan Di Sekolah. Jakarta: PT. Asdi Mahasatya.

Depdiknas, 2007.Pendidikan dan Pelatihan Manajemen Unit Produksi/ Jasa Sebagai Sumber Belajar Siswa dan Penggalian Dana Pendidikan Persekolahan. Jakarta Depdiknas. PP Nomor 19 Tahun 2005 Standar Nasional Pendidikan. Jakarta.

Direktorat Pembinaan SMK, 2012. Panduan Pelaksanaan Tahun 2012 Bantuan
Pengembangan Kewirausahaan SMK/ Teaching Industry. Jakarta: Direktorat Pembinaan SMK.

Djuju Sujana, 2006. Evaluasi Program Pendidikan (Untuk Pendidikan Nonformal dan Pengembangan Sumber Daya Manusia). Bandung: Falah Production.

Farida Yusuf, 2000. Evaluasi Program dan Instrumen Evaluasi. Jakarta. PT Rineka Cipta.

Hamka Abdul Azis, 2012. Karakter Guru Profesional. Jakarta. Al-Mawardi Prima.

Hendra Kusuma, 1999. Manajemen Produksi. Yogyakarta: Andi Yogyakarta.

Hikmat, 2009.Manajemen Pendidikan. Bandung. CV Pustaka Setia.

H Malayu Hasibuan, 2007. Manajemen Sumber Daya Manusia. Jakarta: PT. Bumi Aksara. Jogiyanto, 2014. Pedoman Survei Kuisioner: Mengembangkan Kuesioner, mengatasi bias dan Meningkatkan Respon. Yogyakarta. BPFE-Anggota IKAPI

Journal of Economic Education 1 (1), 2012 ; diakses pada 4 April 2016 jam 09.10 wib

Kemendikbud, 2013. Bahan Pembelajaran Diklat Calon Kepala Sekolah Program Kegiatan Produksi dan Jasa Sekolah/ Madrasah. Jakarta. LPPKS

Ni'matu Sholihah, 2012. Pengelolaan Unit Produksi Bidang Busana di SMK Negeri 3 Malang. Diakses dari http// :mulok.library.um.ac.id pada 29 April 2016 jam 10.55 wib.

Pardjono, 2011. Peran Industri Dalam Pengembangan SMK. Diakses dari http:// staff.uny.ac.id/system/files/pengabdian/profdrs-pardjono-msc-phd/peran-dudi-utksmk.docx pada 28 November 2016 jam 18.10 wib.

PMPTK Depdiknas, 2007. Pedoman manajemen unit produksi/ jasa sebagai sumber belajar siswa dan penggalian dana pendidikan persekolahan.

Peraturan Pemerintah Republik Indonesia Nomor 66 Tahun 2010 Tentang Perubahan 
Atas Peraturan Nomor 17 Tahun 2010 Tentang Pengelolaan Dan Penyelenggaraan Pendidikan.

Pupuh Fathurrohman dan Aa Suryana, 2012. Guru Profesional. Bandung. PT Refika Aditama.

Ridwan, S \& Inge, B, 2002. Manajemen Keuangan 1. Jakarta: PT. Prenhallindo.

Rusnani, 2012. Pelaksanaan Unit Produksi pada SMK Negeri Kelompok Bisnis dan Manajemen (SMK Negeri 1 dan SMK Negeri 3 Banjarmasin (Jurnal Pendidikan Vokasi, Vol 2, Nomor 3, November 2010). Diakses pada 28 April 2016 jam 14.25 wib.
Singgih Darjanto, 2012. Manajemen Unit Produksi dan Jasa di Sekolah Menengah Kejuruan Umar Fatah Rembang (Journal of Economic Education 1 (1), 2012). Diakses pada 4 April 2016 jam 09.10 wib

Suharsimi Arikunto, 2004. Evaluasi Program Pendidikan: Pedoman Teoretis Praktis Bagi Mahasiswa dan Praktisi Pendidikan (EdisiKedua). Jakarta. BumiAksara.

Suharsimi Arikunto, 2009. Prosedur Penelitian Suatu Pendekatan Praktik. Jakarta. PT RinekaCipta.

Wirawan, 2009. Evaluasi Kinerja Sumber Daya Manusia Teori Aplikasi dan Penelitian. Jakarta. Salemba Empat.

Yayat, M Herujito, 2001. Dasar- Dasar Manajemen. Jakarta: PT. Grasindo 